\title{
Familial Alzheimer-like prion disease
}

INSERM

\section{Source}

INSERM. (1999). Orphanet: an online rare disease and orphan drug data base. Familial Alzheimer-like prion disease. ORPHA:280397

Familial Alzheimer-like prion disease is an exceedingly rare form of prion disease (see this term) characterized by the neuropathological features of Alzheimer disease including memory impairment and depression, related to abnormal prion protein (PrP) caused by a gene mutation in PRNP. Patients present with a prolonged, atypical course (absence of myoclonus or ataxia) unlike other forms of prion disease with severe neurofibrillary tangle pathology and high levels of cerebral amyloidosis. 